\title{
Ruth Corrêa Leite Cardoso
}

\author{
Gilberto Velho
}

$\mathrm{O}$ trabalho acadêmico da doutora Ruth Cardoso esteve sempre associado a preocupações com políticas públicas das mais variadas naturezas. Pesquisou a minoria de origem japonesa e sua inserção no Estado de São Paulo. Inaugurou, na Universidade de São Paulo - USP, juntamente com a doutora Eunice Durham, o campo da antropologia urbana, focalizando diversos temas. Estudou, sistematicamente, as condições de vida dos pobres urbanos. Preocupou-se com a problemática da diversidade dos bairros e das áreas das cidades. Coordenou importantes projetos sobre juventude. Sem arrogância teórica, esteve sempre voltada para as discussões sobre questões de método e pesquisa. Como boa parte de sua geração, estudou e participou de grupos de debate sobre marxismo, mas foi também uma leitora sistemática e atenta da obra de Lévi-Strauss, assim como de outras tradições intelectuais, como a Escola socioantropológica de Chicago. Durante sua longa trajetória de docente na USP, foi um dos melhores exemplos de realização de trabalho interdisciplinar. Antropóloga de formação e carreira, por uma série de circunstâncias, passou um longo período no Departamento de Ciência Política. Seu diálogo com sociólogos, economistas e historiadores foi permanente e intenso.

Essa combinação de pesquisa e ensino deu-lhe um perfil de grande influência nos debates e diálogos das ciências sociais brasileiras entre os anos 1950 e 1990. Isso foi somado ao verdadeiro dom de ser uma orien-

DADOS - Revista de Ciências Sociais, Rio de Janeiro, Vol. 51, n-2, 2008, pp. 271 a 274. 
tadora emérita. Supervisionou, coordenou e participou de empreendimentos os mais diversos em grupos de trabalho, seminários, congressos e reuniões científicas. Teve destacada atuação na Associação Brasileira de Antropologia - ABA, na Associação Nacional de Pós-Graduação e Pesquisa em Ciências Sociais - Anpocs e na Sociedade Brasileira para o Progresso da Ciência - SBPC. Sua competência de orientadora se expressou no grande número de teses e dissertações, bem como na variedade de assuntos de investigação que supervisionou. Manteve sempre forte interesse na temática das minorias étnicas e culturais. Preocupou-se com as temáticas de desvio e transgressão. Lidou com as condições de vida e mobilização das camadas populares urbanas e rurais, e com a emigração brasileira. Assumiu o desafio de estudar os setores jovens acompanhando processos de mudança social e de conflito, assim como novas formas e redes de comunicação.

A temática dos movimentos sociais foi uma das áreas em que investiu boa parte de sua carreira, abrindo alternativas para investigações mais atentas às dinâmicas da sociedade contemporânea. Foi uma das mais importantes cientistas sociais voltadas para a temática do feminismo e da questão do gênero em geral. Contribuiu, por meio de diferentes iniciativas, para legitimação e profundidade de debates e investigações desse tema. Uma das condições básicas para o exercício de suas qualidades acadêmicas foi a notável abertura para os temas do mundo, combatendo preconceitos e posições dogmáticas. Valorizava o debate com colegas e alunos, sendo gentil nessa aproximação, o que não impedia que defendesse firmemente seus pontos de vista. Tive oportunidade de vê-la participar de debates acalorados em que jamais perdeu a compostura e a elegância. Acompanhou-a claramente por toda a carreira a preocupação com o tema da educação em todos os níveis. Procurava lidar com essa complexa temática do modo mais aberto possível, sempre atenta aos debates internacionais. Juntamente com o marido, o sociólogo Fernando Henrique Cardoso, viajou e freqüentou diferentes universidades e centros de pesquisa pelo mundo. Foi professora visitante e pesquisadora convidada em diversas instituições nacionais e internacionais. O curso que ministrou no Museu Nacional, no início dos anos 1980, até hoje é lembrado por sua relevância. Sua já mencionada participação nas associações científicas se traduziu na coordenação de grupos de trabalho, especialmente na Anpocs e na ABA, em que reuníamos profissionais e estudantes de diversas procedências para apresentar trabalhos e debater questões de pesquisa. Esses eventos muito contribuíram para a produção de importantes estudos, como teses, dis- 
sertações, artigos e livros. Ruth Cardoso se destacava por abrir portas e criar espaços. Foi por isso que exerceu papel de liderança na vida universitária; de modo discreto, mas denso e marcante. Teve muitos alunos, orientandos ou não, que sofreram sua influência não só acadêmica, no sentido mais estrito, mas também pessoal, de modo mais amplo. Essencialmente, isso consistia em um aprendizado do respeito pelo trabalho alheio e na crença da importância da ação coletiva que, sem esmagar individualidades, abria terreno para encontros, diálogos e descobertas comuns.

Todo esse capital construído durante sua vida acadêmico-universitária a acompanhou no outro lado de sua trajetória existencial. Fernando Henrique, seu marido, direcionou-se para uma carreira política que culminou em dois mandatos como presidente da República. Durante os primeiros tempos, Ruth se manteve atuante tanto na USP quanto no Centro Brasileiro de Análise e Planejamento - Cebrap, instituição em que desempenhou papel-chave, muito contribuindo para sua função original e inovadora. Como esposa de presidente da República, conseguiu superar os desempenhos mais convencionais e, por meio de seu trabalho, voltado para políticas públicas, reinventou o papel de "primeira-dama". Refletiu profundamente e produziu políticas sociais inovadoras por intermédio do programa Comunidade Solidária - que vigorou durante os dois mandatos de Fernando Henrique Cardoso -, estimulando iniciativas e abrindo oportunidade para efetivos projetos de cidadania. Rejeitou o clientelismo e o paternalismo. Estimulou a criatividade e a inovação. Terminado o mandato presidencial, permaneceu trabalhando com a organização não-governamental Comunitas - criada em 2000 para garantir a continuidade dos projetos iniciados pela Comunidade Solidária -, além de ter participado de diversas outras iniciativas direcionadas à construção de uma sociedade democrática que enfrenta permanentemente a desigualdade social, a corrupção e o abuso de poder. Por tudo isso, Ruth Cardoso teve uma vida exemplar, interrompida de modo brusco e chocante. Sua obra e seus exemplos permanecerão como referências não só para a nossa comunidade de cientistas sociais mas também para toda a nação brasileira. 


\section{BIBLIOGRAFIA SELECIONADA}

CARDOSO, Ruth Corrêa Leite. (1959), “O Papel das Associações Juvenis na Aculturação dos Japoneses". Revista de Antropologia, vol. 7, pp. 101-122.

. (1963), “O Agricultor e o Profissional Liberal entre os Japoneses no Brasil”. Revista de Antropologia, vol. 11, pp. 53-60.

. (1963), “Organização Familiar entre os Japoneses de São Paulo". Revista do Museu Paulista, no 14, pp. 277-282.

. (1984), "Movimentos Sociais Urbanos: Balanço Crítico", in B. Sorj e M. H. T. de Almeida (orgs.), Sociedade e Política no Brasil Pós-64. São Paulo, Brasiliense.

. (1988), "Os Movimentos Populares no Contexto da Consolidação Democrática", in F. W. Reis e G. O’Donnell (orgs.), A Democracia no Brasil: Dilemas e Perspectivas. São Paulo, Verbo.

. (1994), “A Trajetória dos Movimentos Sociais”, in E. Dagnino (org.), Os Anos 90: Política e Sociedade no Brasil. São Paulo, Brasiliense, pp. 81-90.

. (1998) [1972], Estrutura Familiar e Mobilidade Social: Estudo dos Japoneses no Estado de São Paulo. São Paulo, Kaleidos-Primus Consultoria e Comunicação Integrada.

(org.). (1986), A Aventura Antropológica: Teoria e Pesquisa. Rio de Janeiro, Paz e Terra.

CARDOSO, Ruth Corrêa Leite e SAMPAIO, Helena. (1995), Bibliografia sobre a Juventude. São Paulo, Edusp. 